\title{
The excitable signal transduction networks: movers and shapers of eukaryotic cell migration
}

\author{
DHIMAN S. PAL ${ }^{\#, 1},{\text { XIAOGUANG LI" }{ }^{\#, 1,2}, \text { TATSAT BANERJEE }}^{1,3}$, YUCHUAN MIAO $^{1,2}$ \\ and PETER N. DEVREOTES*,1 \\ ${ }^{1}$ Department of Cell Biology and Center for Cell Dynamics, School of Medicine, ${ }^{2}$ Department of Biological Chemistry,
School of Medicine and ${ }^{3}$ Department of Chemical and Biomolecular Engineering. Whiting School of Engineering, \\ Johns Hopkins University, Baltimore, MD, USA
}

\begin{abstract}
In response to a variety of external cues, eukaryotic cells display varied migratory modes to perform their physiological functions during development and in the adult. Aberrations in cell migration result in embryonic defects and cancer metastasis. The molecular components involved in cell migration are remarkably conserved between the social amoeba Dictyostelium and mammalian cells. This makes the amoeba an excellent model system for studies of eukaryotic cell migration. These migration-associated components can be grouped into three networks: input, signal transduction and cytoskeletal. In migrating cells, signal transduction events such as Ras or PI3K activity occur at the protrusion tips, referred to as 'front', whereas events such as dissociation of PTEN from these regions are referred to as 'back'. Asymmetric distribution of such front and back events is crucial for establishing polarity and guiding cell migration. The triggering of these signaling events displays properties of biochemical excitability including all-or-nothing responsiveness to suprathreshold stimuli, refractoriness, and wave propagation. These signal transduction waves originate from a point and propagate towards the edge of the cell, thereby driving cytoskeletal activity and cellular protrusions. Any change in the threshold for network activation alters the range of the propagating waves and the size of cellular protrusions which gives rise to various migratory modes in cells. Thus, this review highlights excitable signal transduction networks as key players for coordinating cytoskeletal activities to drive cell migration in all eukaryotes.
\end{abstract}

KEY WORDS: signaling wave, polarity, PIP3, macrophage, phagocytosis, cytokinesis, cancer

Dictyostelium paves the way for understanding cell migration in human health and disease

In eukaryotic cells, cell migration is crucial for a multitude of physiological processes. During embryogenesis, migration of individual or groups of cells, in response to external cues, leads to formation of various glands and organs, and wiring of the nervous system (Montell, 2008). Examples include the coordinated movement of epithelial cell sheets at the onset of gastrulation and neurulation (Keller, 2005, Leptin, 2005, Theveneau and Mayor, 2012, Yang et al., 2002), movement of primordial germ cells across the embryo towards the developing somatic gonads (Blaser et al., 2006, Richardson and Lehmann, 2010) or glial and neural precursor cell migration in the central and peripheral nervous systems (Klambt, 2009). In adults, directed migration is observed during host inflam- matory responses when immune cells move through tissues and vessels towards invading pathogens (Nourshargh and Alon, 2014, Weninger et al., 2014), or various cellular regenerative processes such as wound healing performed by concerted movement of fibroblasts and keratinocytes (Shaw and Martin, 2009). Cells are able to sense and integrate a variety of external cues from the environment and each other, including chemicals (Bagorda and Parent, 2008, Tessier-Lavigne, 1994), electric fields (Cortese et

\footnotetext{
Abbreviations used in this paper: PIP3, phosphatidylinositol (3,4,5)-trisphosphate; $\mathrm{PI}(3,4) \mathrm{P} 2$, phosphatidylinositol 3,4-bisphosphate; $\mathrm{PI}(4,5) \mathrm{P}$, phosphatidylinositol 4,5-bisphosphate; PTEN, phosphatase and tensin homolog; PI3K, phosphoinositide 3-kinase; GPCR, G-protein-coupled receptor; cAMP, 3',5'-cyclic adenosine monophosphate; cARs and FARs, cAMP and folic acid receptors; STEN, signal transduction excitable networks; CEN, cytoskeletal excitable networks.
}

\footnotetext{
*Address correspondence to: Peter N. Devreotes. Department of Cell Biology and Center for Cell Dynamics, School of Medicine, Johns Hopkins University, Baltimore, MD 21205, USA. E-mail: pnd@jhmi.edu - (iD) https://orcid.org/0000-0002-3260-1455
}

\#Note: The indicated authors contributed equally to this article. 
al., 2014, Gao et al., 2011, Zhao et al., 2006), light (Armitage and Hellingwerf, 2003), temperature (Ramot et al., 2008, Whitaker and Poff, 1980) and mechanical forces (Harland et al., 2011, Lo et al., 2000). Irregularities or defects in cell migration are responsible for pathogenesis of several inflammatory diseases such as acute respiratory distress syndrome, several allergies (asthma, allergic rhinitis and atopic dermatitis), arthritis, atherosclerosis, periodontal disease, sarcoidosis and Wiskott-Aldrich syndrome (Lakshman and Finn, 2001, Moulding et al., 2013). Cell migration is also a crucial phenomenon during cancer metastasis when tumor cells detach and spread from their primary site of origin to colonize other tissues and organs of the body (Kedrin et al., 2007).

Eukaryotic cells perform their crucial physiological functions by displaying a variety of migratory behaviors. Migration in these cells is achieved by coordinated extension of actin-rich protrusions at the leading edge of the cell, and actomyosin filaments-based contraction at the trailing edge (Fig. 1A). Variations of this cytoskeletal organization in the cell give rise to a vast repertoire of migratory behaviors. Leukocytes, hematopoietic stem cells and several metastatic cancer cells translocate by amoeboid motility, a rhythmic extension and retraction of actin-filled pseudopodia

A

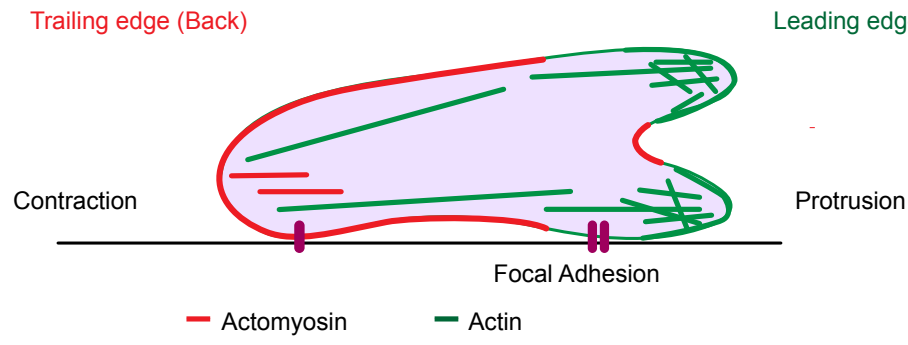

B

Dictyostelium

Mammalian cells

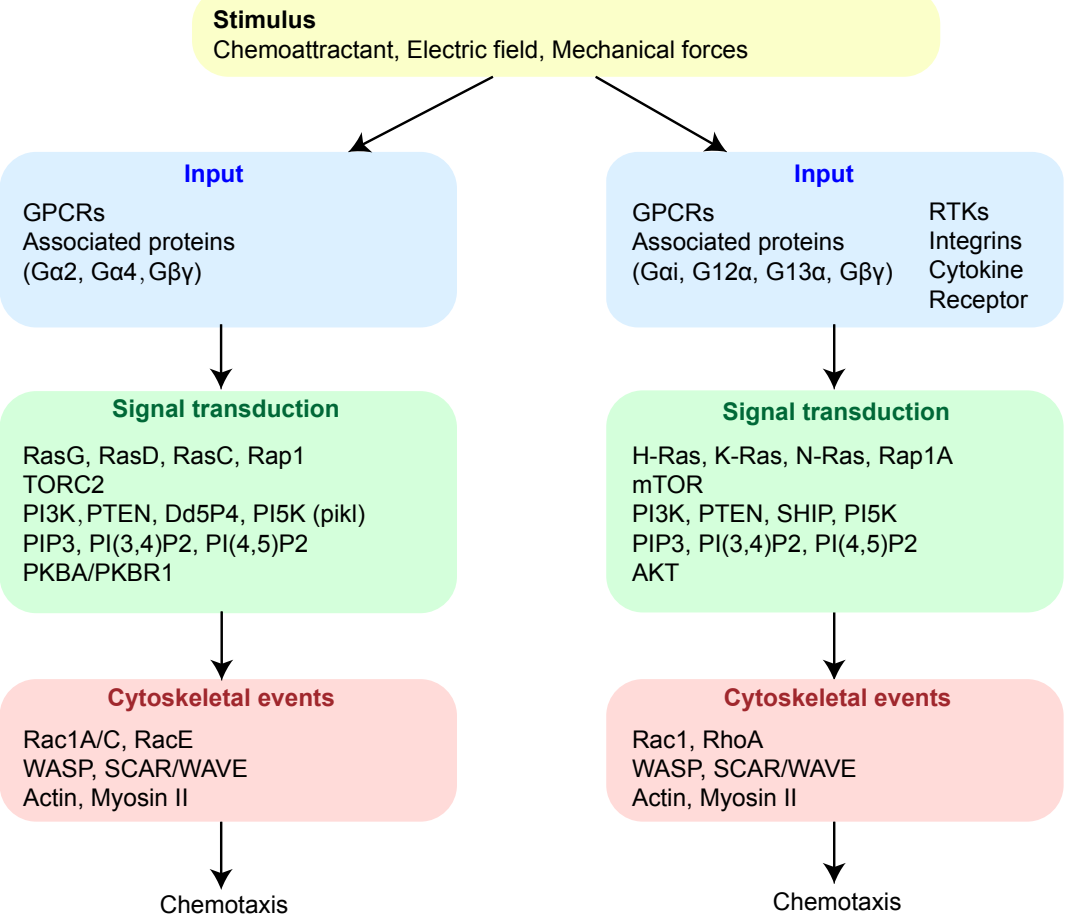

leading to cell movement in random directions. Primordial germ cells use an unusual type of amoeboid motion, termed as blebbing, which involves extension of rounded cytoplasmic bulges caused by detachment of plasma membrane from actomyosin cortex due to myosin-based contraction (Blaser et al., 2006, Fackler and Grosse, 2008, Yoshida and Soldati, 2006). Keratocyte-like migration, seen in mesenchymal-derived corneal stromal cells, is characterized by large, actin-driven, fan-like lamellipodia at the front and sides of the cell causing them to move in a rolling motion (Barnhart et al., 2010). This mechanism leads to the fastest motion and cells can maintain constant direction and speed over several cell lengths (Anderson and Cross, 2000). "Mesenchymal" migration, seen in fibroblasts, is much slower than amoeboid or keratocyte-like motility and is mediated by lamellipodia at the leading edge of the cell (Hou et al., 2012). This type of migration depends on focal adhesions between cell and extracellular matrix whereas amoeboid or keratocyte migration involves more transient attachment of cells to the substratum (Mogilner and Keren, 2009, Parsons etal., 2010). In this review, the focus primarily would be on understanding the signal transduction events in amoeboid migration in cells, although it is explained how cells can abruptly switch between migratory modes.

Most of the present-day knowledge regarding amoeboid-type migration in eukaryotic cells was first revealed from seminal studies in the social amoeba, Dictyostelium. For example, identification of actin binding proteins such as coronin (de Hostos et al., 1991), functional redundancy of cytoskeletal components involved in cell migration (Andre et al., 1989, Jung et al., 1996, Witke et al., 1992), role of myosin II in cytokinesis and cell migration (De Lozanne and Spudich, 1987, Wessels et al., 1988), identification of chemoattractant receptors as GPCRs (Klein et al., 1988), confinement of phosphoinositide lipids and $G$ protein signaling events to the leading edge of migrating cells (lijima and Devreotes, 2002, Parent et al., 1998), involvement of Ras GTPases in cell migration (Insall et al., 1996, Kae et al., 2004, Sasaki et al., 2007), and discovery of actin waves (Vicker, 2002). Due to evolutionary conservation between

Fig. 1. Molecular components involved in eukaryotic migration. (A) Eukaryotic migration is achieved by extending actin-rich protrusions at the leading edge of the cell (as shown in dark green), coordinated with actomyosin-based contraction at the trailing edge (denoted in dark red). These cells develop active sites for actin polymerization, called focal adhesions, underneath the leading edge for integrindependentadhesion and migration. (B) Independent genetic and biochemical experimentation have identified various components involved in directed cell migration which can be grouped into 3 networks-input, signal transduction, and cytoskeletal events. The important components for each of these networks have been highlighted in the cartoon. A variety of external stimuli, such as chemoattractant (chemicals), electric fields and mechanical forces, locally activate the signal transduction networks through input networks, leading to cytoskeletal events such as F-actin polymerization at the front and actomyosin-based contraction at the back of the cell. The coordinated activation of these networks results in chemotaxis (directed cell migration) and is functionally conserved in Dictyostelium (left) and mammalian cells (right). 


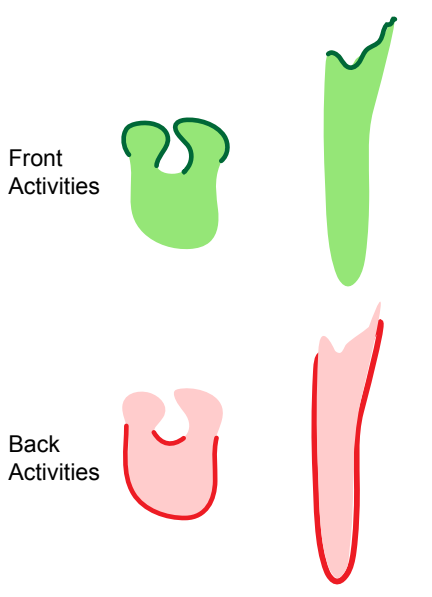

Vegetative Cell Developed Cell Cytokinesis
Fused Giant Cell
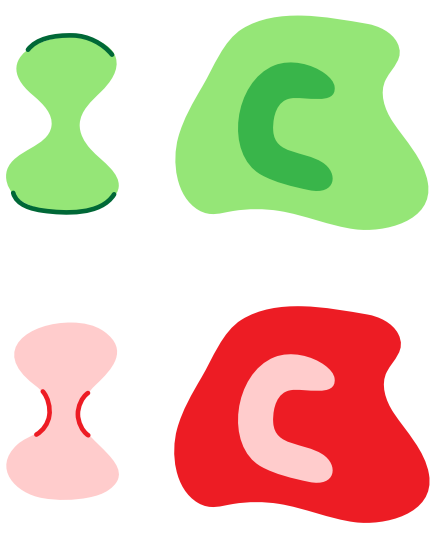

Latrunculin A-treated Cell
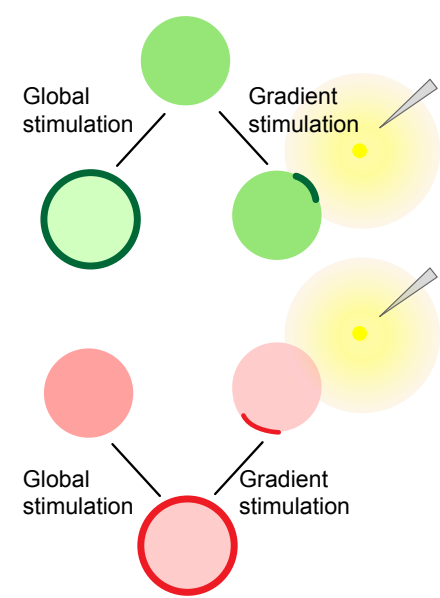

Fig. 2. Complementary distribution pattern of front and back activities in Dictyostelium cells undergoing various morphological changes. Front activities, such as Ras or PI3K activation, occurat the macropinocytic cups or protrusions of migrating vegetative or developed cells, respectively (denotedin darkgreen, top row). These frontactivities are complemented with back activities at the trailing edge of the macropinocytic cups or cell (denoted in dark red, bottom row). During cytokinesis, these front molecules are found at the poles of the dividing cells (denoted in dark green, top row) and the back molecules accumulate at the cleavage furrow (shown in dark red, bottom row). In motile 'giant' Dictyostelium cells, generated by electric-pulse-induced fusion, majority of the basal surface is marked by biosensors for back molecules (shown in dark red, bottom row), except in the region of F-actin polymerization where the front molecules are present (shown in dark green, top row). Upon global or gradient chemoattractant stimulation, latrunculin A-treated cells show opposite distribution of front (shown in dark green, top row) and back (shown in dark red, bottom row) activities.
Dictyostelium and higher eukaryotes, these scientific discoveries paved the way for understanding the role of migration-associated signal transduction and cytoskeletal networks in human physiology and pathology (Bagorda et al., 2006, Parent, 2004).

The amenability of Dictyostelium to experimentation enabled these discoveries. It is easily cultivable in the laboratory, and is well suited for live cell imaging. It has a haploid genome which is completely sequenced and annotated, thereby facilitating genetic manipulations (Muller-Taubenberger et al., 2013). Moreover, Dictyostelium are naturally migratory cells which respond to chemoattractants, such as cAMP, as part of their development program, and folic acid to seek nutrients (Chisholm and Firtel, 2004, Mahadeo and Parent, 2006). These processes can be mimicked in the laboratory with relative ease which makes the amoeba the premier model system for investigating cell migration.

\section{Spatiotemporal control of signal transduction networks regulates cell migration}

The components involved in cell migration can be grouped into input, signal transduction, and cytoskeletal networks, which show functional conservation between Dictyostelium and mammalian cells (Fig. 1B). Chemical, electrical or mechanical stimuli locally activate the signal transduction networks through input networks which consists of different receptors or sensors (Allen et al., 2013, Meng et al., 2011, Miao et al., 2017, Zhao et al., 2002, Zhao et al., 2006). In Dictyostelium, the input network is comprised of cAMP and folic acid GPCRs (cARs and FARs respectively) along with associated $\mathrm{G}$ proteins ( $\mathrm{G} \alpha 2, \mathrm{G} \alpha 4, \mathrm{G} \alpha 9$ and $\mathrm{G} \beta \gamma$ ) (Kimmel and Parent, 2003, Klein et al., 1988, Pan et al., 2016, Parent and Devreotes, 1996, Wu and Devreotes, 1991). The input network of mammalian cells consists of GPCRs and associated G proteins (G $\alpha$ i, G12 $\alpha, G 13 \alpha$ and G $\beta \gamma$ ), RTKs, integrins and chemokine receptors (Fig. 1B) (Baggiolini, 2001, Manes et al., 2005, Senoo et al., 2016, Stephens et al., 2008). Chemokine receptors have been found to be functionally similar to cARs and FARs in Dictyostelium. These sensors detect gradients of chemoattractants (cAMP and folic acid for Dictyostelium or chemokines, cytokines and growth factors for mammalian cells) in the environment, thereby triggering downstream signal transduction components and enabling the cell to migrate along the gradient (Jin et al., 2008).

The signal transduction network is comprised of components which are arranged in several interconnected or parallel pathways. In Dictyostelium, it consists of various molecules including Ras proteins (RasG, RasD and RasC), phosphoinositide lipids [phosphatidylinositol $(3,4,5)$-trisphosphate or PIP3, phosphatidylinositol 3,4-bisphosphate or PI $(3,4) \mathrm{P} 2$ and phosphatidylinositol 4,5-bisphosphate or PI(4,5)P2], and several lipid kinases/phosphatases (PI3K, PTEN and Dd5P4) and protein kinases/phosphatases (PKBA/ PKBR1). The signaling network in mammalian cells is analogous including $\mathrm{H}$-Ras, K-Ras, PIP3, PI(3,4)P2, PI(4,5)P2, PI3K, PTEN, SHIP and AKT (Fig. 1B) (Devreotes and Horwitz, 2015, Devreotes et al., 2017, Simanshu et al., 2017, Tang et al., 2011, Wilkins and Insall, 2001). Studies suggest that the role of the Ras-PIP3 network in mammalian cell migration is remarkably consistent with that in Dictyostelium (Artemenko et al., 2014). Other reports have shown that interactions between Ras/Rap1 family proteins and TORC2 are conserved and thereby coordinate migration in Dictyostelium and mammalian cells (Charest et al., 2010, Khanna et al., 2016). Importantly, these network events are spontaneously activated leading to cell migration even in absence of an external cue (Arai et al., 2010, Bosgraaf and Van Haastert, 2009, Sasaki et al., 2007, Xiong et al., 2010).

The signal transduction network connects to the cytoskeletal network, and controls organization of the acto-myosin cytoskeleton which drives cell migration. In Dictyostelium and mammalian cells, the cytoskeletal network is made up several components which include Rho family G proteins, myosin II, SCAR/WAVE complex, Arp 2/3 complex and coronin (Fig. 1B) (Alvarez-Gonzalez et al., 2014, Wilkins and Insall, 2001). Of these components, the Rho family GTPases are a crucial convergence point of migrationassociated signaling. In mammals, cell migration-related research has been focused on Rac1, RhoA and Cdc42 proteins of the Rho family whereas 15 Rho family proteins are present in Dictyostelium. 
A
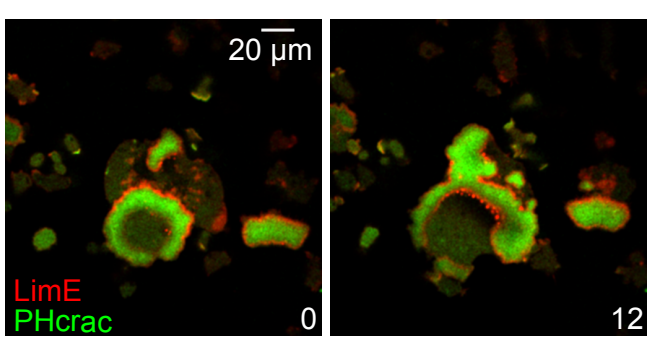

B
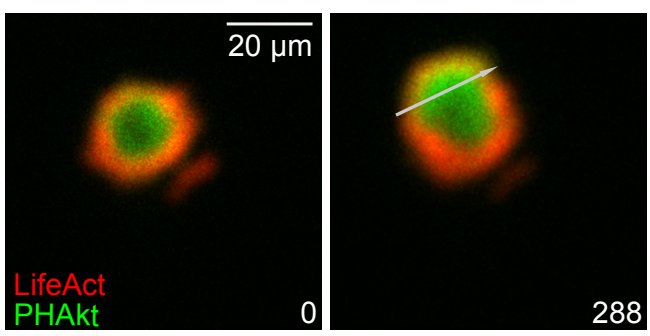
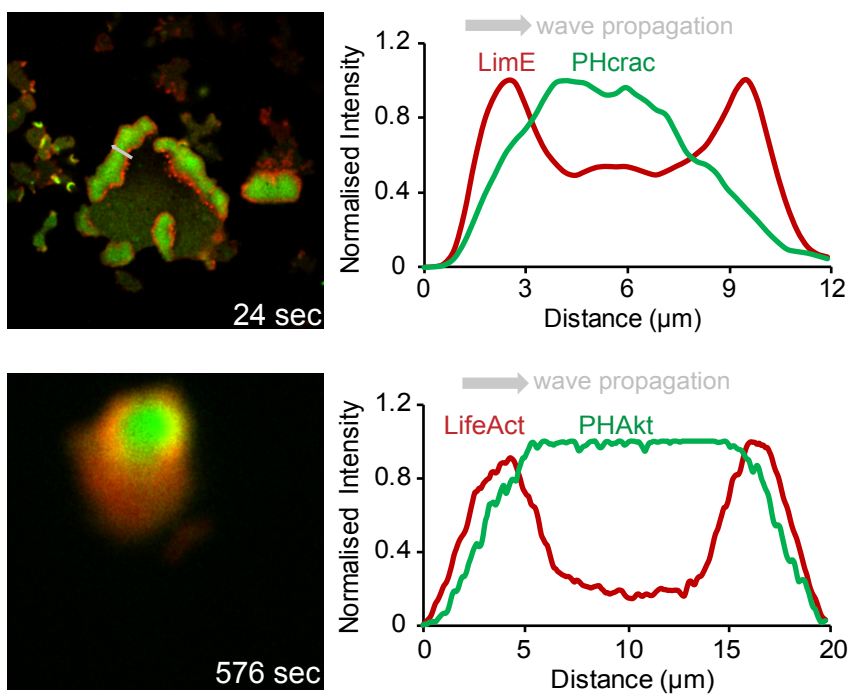

Fig. 3. Conservation of PIP3 and F-actin waves in Dictyostelium and mammalian cells. (A) Time lapse merged confocal images showing distribution of F-actin biosensor, LimEAcoil or "LimE" (red) and PIP3 biosensor, PHcrac (green) in waves at the basal surface of a migrating fused Dictyostelium cell (left). Intensity plot across the white arrow in image "24 sec" (right). Prior to imaging, fused cells were generated by electroporation of single cells at 1,000 V, $3 \mu \mathrm{F}$ for once, and 1,000 V, $1 \mu \mathrm{F}$ for three times, with 1-2 secs between pulses. (B) Time lapse merged confocal images of F-actin biosensor, LifeAct (red) and PIP3 biosensor, PHAkt (green) in waves at the basal surface of a RAW 264.7 macrophage cell undergoing frustrated phagocytic spreading on an anti-BSA IgG coated glass surface (left). Intensity plot across the white arrow in image "288 sec" (right).

These proteins act on a number of effectors, thereby regulating protrusion, adhesion and polarization during migration (Lawson and Ridley, 2018, Lim et al., 2002, Ridley, 2015). Studies have shown that there is functional conservation between mammalian Rac1 and RhoA and Dictyostelium Rac1A/C and RacE, respectively (Filic et al., 2012, Wang et al., 2013a, Wang et al., 2013b). Further evidence for this was put forward in a recent study which shed light on a novel interaction between phosphorylated GDP-bound RacE or RhoA and mTORC2 kinase, resulting in downstream AKT phosphorylation in Dictyosteliumand mammalian cells, respectively (Senoo et al., 2019).

In migrating cells, many components of the signal transduction network selectively translocate to, or are activated on, protrusions tips while others, initially present on the cortex dissociate from the protrusions. These sets of components are referred to as "front" or "back", respectively (Fig. 2). For example, "front" biosensors for Ras or PI3K activation and PIP3 accumulation reside in the cytosol and are recruited to the tips of pseudopodia as protrusions form. On the other hand, "back" proteins such as PTEN and myosin are present uniformly in the cortex and dissociate from the regions where protrusions are formed (Filic et al., 2012, Kriebel et al., 2008, Lam et al., 2012, Matsuoka and Ueda, 2018, Parent, 2004, Tsai et al., 2019, Xu et al., 2017). Such complimentary distribution of front and back components is observed in an extensive set of other morphological changes. For example, the pattern is preserved in macropinosomes and pseudopods and during cytokinesis where front molecules accumulate at the poles of the dividing cell and back molecules localize to the cleavage furrow (Fig. 2) (Janetopoulos et al., 2005). A complementary pattern of front and back events is also observed in motile polykaryotic Dictyostelium cells, which are formed in response to electric pulsing of single cells, and have been recently used for imaging large-scale pattern dynamics independently of boundary effects (Gerisch et al., 2013). A major portion of the basal surface of these fused 'giant' cells is marked by biosensors for back components, except in the region of $\mathrm{F}$-actin polymerization where the front molecules are present (Fig. 2). Furthermore, in presence of a global chemoattractant stimulation, all front components of an actin polymerization inhibitor (latrunculin A)-treated cell translocate from the cytosol to distribute uniformly over the cortex or membrane whereas the back molecules fall off from the cell periphery into the cytosol (Fig. 2). When latrunculin A-treated cells are subjected to a chemoattractant gradient, membrane patches for the front components are enhanced at the high side of the gradient, and suppressed at the low side. The back components follow an exactly complementary localization pattern on the membrane in response to a spatial gradient (Fig. 2) (lijima and Devreotes, 2002, lijima et al., 2004, Janetopoulos et al., 2004, Parent et al., 1998, Sasaki et al., 2004). A comprehensive list of signaling components that translocate to front or back of cells is provided previously (Swaney et al., 2010).

Asymmetric accumulation of front and back components is crucial for promoting actin polymerization and producing cellular protrusions for cell migration. In cells expressing constitutively active RasC (Q62L), F-actin polymerization appears at ectopic sites around the cell periphery resulting in increased protrusions and reduced directionality to the chemoattractant source (Cai et al., 2010). Excess accumulation of PIP3 along the entire cell periphery in neutrophils lacking SHIP1 or Dictyostelium lacking PTEN, gives rise to ectopic lateral pseudopodia outside the leading edge. If these cells are treated with LY294002 (PI3K inhibitor), this phenotype is reverted to a single anterior pseudopod in the cells (Chen et al., 2003, Funamoto et al., 2002, lijima and Devreotes, 2002, Nishio et al., 2007). Various studies involving uniform activation or pharmacological inhibition of PI3K have shown that altering levels of PIP3 alone is sufficient to affect directed and random migration in neutrophils, fibroblasts, germ cells, cancer cells, and Dictyostelium 
A

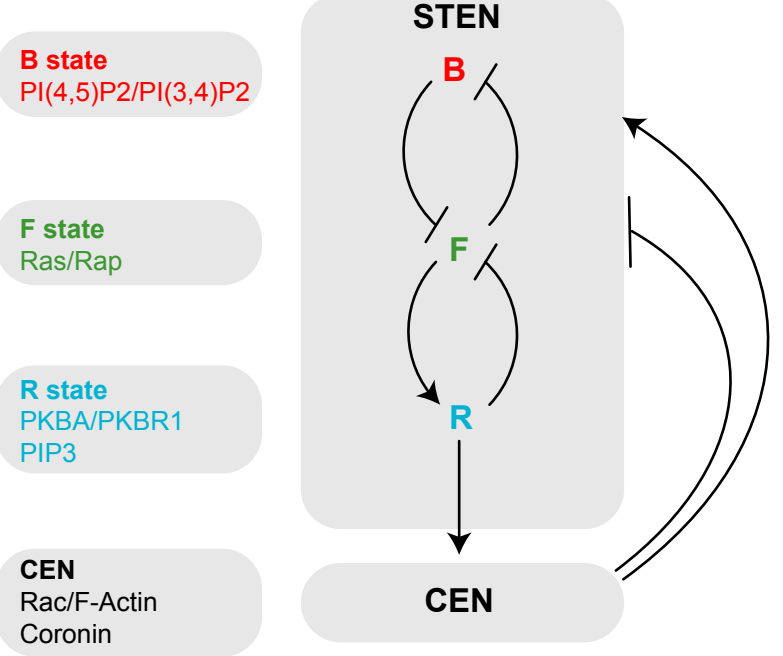

B

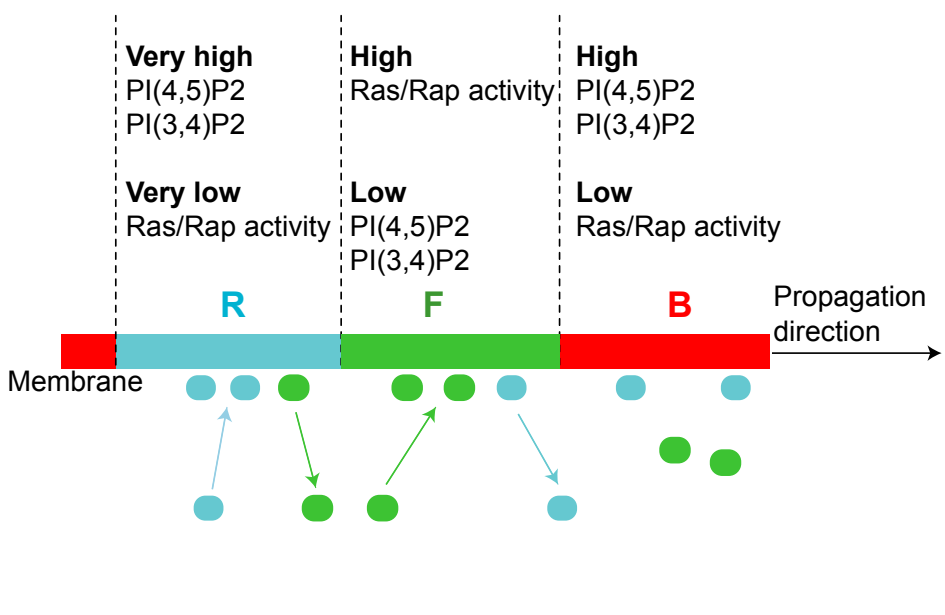

Fig. 4. Feedback loops and state of network components of signal transduction excitable networks (STEN). (A) The STEN-CEN model architecture showing B (inactive, red), F (active, green) and R (refractory, blue) states of STEN and the feedback connections between STEN and CEN. The positive feedback is indicated through the arrowhead, whereas the bar at the end of the arrow refers to negative feedback. Positive feedback is due to mutual inhibition between $F$ (activation of Ras/Rap) and B (PIP2) states at the cell cortex, and a delayed negative feedback from $R$, due to delayed PKB activation by PIP3, to F state. The PKBs (R state) feeds into CEN and promotes F-actin polymerization which, in turn, provides a fast positive and slow negative feedbacks to STEN. (B) A representative portion of the cortical membrane depicting regions where the STEN is in $B$ (red), $F$ (green) and $R$ (blue) states. Due to the various positive and negative feedbacks in STEN-CEN, the F state of the cell cortex is characterized by high Ras/Rap activity and low PI(4,5)P2/PI(3,4)P2 level whereas the $B$ state is denoted by high PI(4,5)P2/PI/(3,4)P2 level and low Ras/Rap activity. The $R$ state, which follows the $F$ state, is characterized by very high PI(4,5)P2/PI(3,4)P2 level and very low Ras/Rap activity. These positive and negative feedbacks along with diffusion of network components, advances the wave unidirectionally (black arrow). Abbreviations: STEN, signal transduction excitable networks; CEN, cytoskeletal excitable networks.

(Chen et al., 2003, Devreotes and Horwitz, 2015, Dumstrei et al., 2004, Ferguson et al., 2007, Hoeller and Kay, 2007, Inoue and Meyer, 2008). In cells lacking the 5-phosphatase, Dd5P4, depletion of $\mathrm{PI}(3,4) \mathrm{P} 2$ leads to increased Ras activity, cell spreading and aberrant migratory behavior (Li et al., 2018). Therefore, role of signal transduction networks in cell migration across various species is well-established.

\section{Role of excitability in Dictyosteliumand mammalian cells}

Although the networks shown in Fig. 1B depicta linear interaction between inputs, signal transduction and cytoskeletal events, such a linear interaction is not sufficient to explain increasing instances of actin wave propagation. Seminal experiments of M.G. Vicker provided the first evidence of spiral localization patterns of actin filament assembly in vegetative-stage Dictyostelium cells (Vicker, 2002). Actin wave generation and propagation in Dictyostelium cells was further characterized and confirmed by Gerisch et al., (Bretschneider et al., 2004, Gerisch, 2010). Coordinated waves of Ras activity, PIP3, PTEN and actin were observed in Dictyostelium which provided a basis for modeling the nonlinear interactions that produce spatio-temporal patterns in the actin system of cells (Arai et al., 2010, Fukushima et al., 2019, Gerisch et al., 2012, Xiong et al., 2016, Xiong et al., 2010). Signal transduction or cytoskeletal waves were then reported by a growing number of studies in various types of mammalian cells such as neutrophils (Hepper et al., 2012, Weiner et al., 2007), macrophages (Masters et al., 2016), fibroblasts (Case and Waterman, 2011), Xenopuseggs (Bement et al., 2015), mast cells (Colin-York et al., 2019, Wu et al., 2013, Xiong et al., 2016), keratocytes (Barnhart et al., 2011), cultured neurons (Winans et al., 2016), and cancer cells (Marchesin et al., 2015). Waves of signaling (PIP3) and cytoskeletal components (actin filaments) show a distinct dynamic pattern with respect to each other (Gerhardt et al., 2014, Gerisch et al., 2011). In fused Dictyostelium cells, F-actin (denoted by its biosensor, LimE) appears as narrow "leading" and "trailing" bands separated with intermediate intensity while PIP3 (denoted by its biosensor, PHcrac) initiates with the leading edge and trails off through the entire region. PIP3/F-actin waves in fused Dictyostelium show similar patterns in mammalian cells such as macrophages. An example is shown in Fig. 3.

To explain wave propagation, and other features of the signal transduction networks (shown in figures $1 \mathrm{~B}$ and $4 \mathrm{~A}$ ) including spontaneous activations, and refractory periods, we have proposed that this network is excitable. Within the signal transduction excitable network (STEN), an activator triggers a fast, autocatalytic loop that generates positive feedback, and a slower inhibitor forms a delayed negative feedback loop. As the activator and inhibitor diffuse, the activities of these processes travel throughout the medium in the form of a propagating wave (Iglesias and Devreotes, 2012). A number of mathematical models consisting of such reaction-diffusion equations for actin waves have also been proposed to capture wave formation and propagation (Bement et al., 2015, Hecht et al., 2010, Meinhardt and de Boer, 2001, Miao et al., 2019, Xiong et al., 2010). Further refinement of this model proposes that local regions of the cell cortex transition between inactive, active, and refractory states, designated as back $(B)$, front $(F)$, and refractory (R) states, respectively. The back and front markers such as PTEN and PI3K, usually associate with the B and F states of the cell 
A

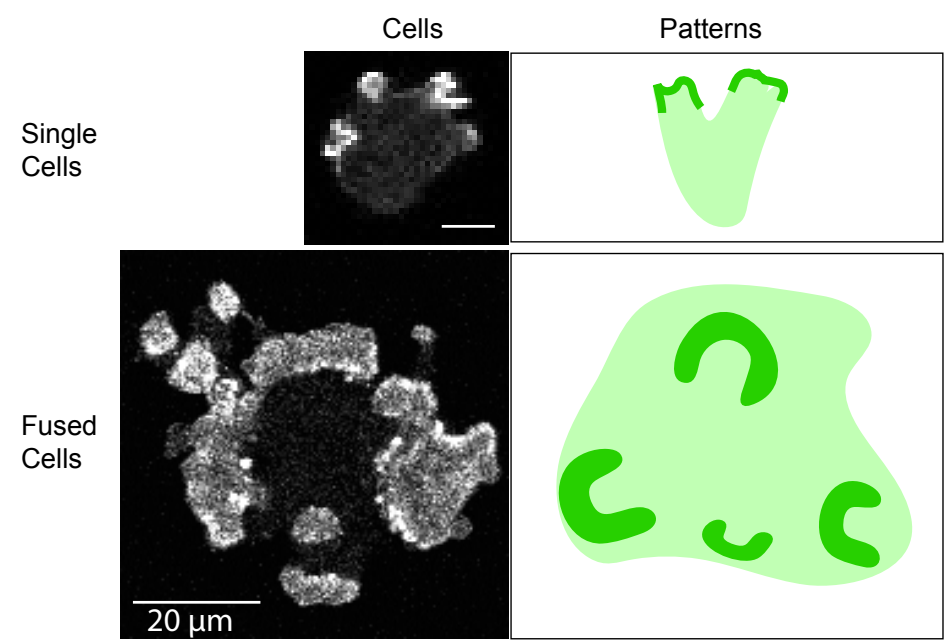

B

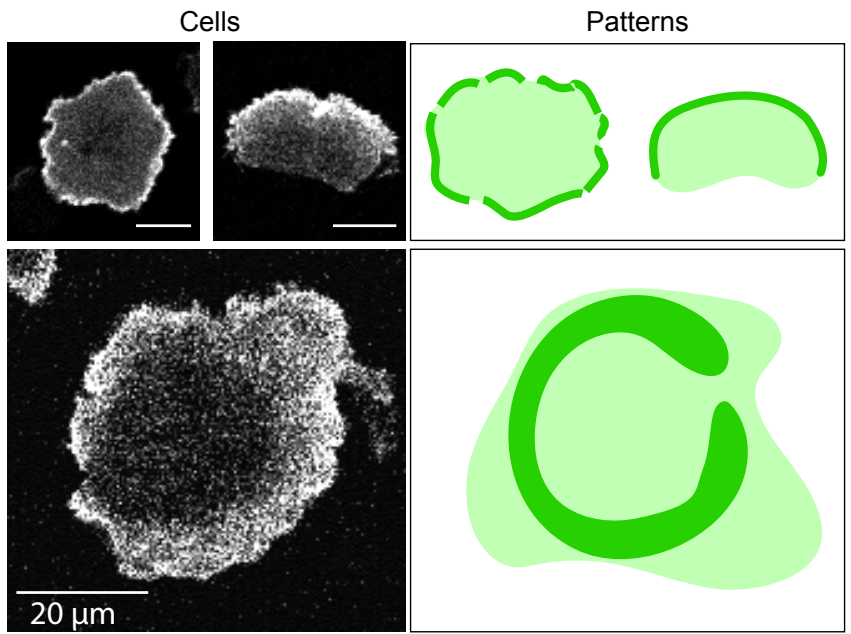

Fig. 5. Perturbation of signal transduction excitable networks (STEN) threshold alters wave behavior and ultimately changes protrusion pattern necessary for cell migration. Confocal images or cartoons showing LimE (F-actin biosensor) wave patterns on the basal surface of single (top) or fused (bottom) Dictyostelium cells, in absence (A) or presence (B) of synthetic perturbation to the threshold for STEN activation. In these experiments, the threshold for STEN activation was lowered by reducing PIP2 levels or increasing Ras/Rap activities at the cell cortex using the chemically inducible dimerization (CID) system. In single cells, such a perturbation causes the size of cellular protrusions to expand from small macropinosomes or pseudopodia (A) (top row) to wide, sheet-like protrusions resembling lamellipodia (B) (top row). This ultimately changes the migratory mode of the cells from amoeboid to oscillatory or fan-shaped. For the amoeboid cells, the waves start at a distinct point and extinguish after a few micrometers of travelling (A) (top row). In case of the 'oscillators', the wave initiates from a much bigger region, expands and covers the basal membrane of the cell momentarily, before extinguishing from the centre outward resulting in the collapse of the cell (B) (top row). In the fan-shaped cell, the expansion of the wave is similar, but asymmetric and therefore pushes out a wide band on the front of the cell (B) (top row). After acute lowering of PIP2 at the cortex of the fused cells, the waves propagate symmetrically without stopping in all directions (B) (bottom row), in comparison to waves in the unperturbed cells, which have asymmetric expansion patterns, smaller range and break up easily (A) (bottom row). These waves also propagate with a significantly faster speed in comparison to those seen in the unperturbed cells.

cortex. The $\mathrm{B}$ and $\mathrm{F}$ regions are mutually inhibitory, and therefore, create the positive feedback loop. The $\mathrm{F}$ and $\mathrm{R}$ states are related through a delayed negative feedback loop (Fig. 4A). In resting cells, most of the cortex is in the B state. Once initiated, waves propagate outwardly because diffusion of F-state components triggers activation in adjoining $B$ but not $R$ regions. The trailing $R$ region ensures unidirectionality of the waves and their annihilation upon crossing each other (Fig. 4B) (Miao et al., 2017).

Studies in multiple labs are beginning to delineate the architecture of the signal transduction and cytoskeletal networks. In STEN, evidence suggests that a mutually exclusive interaction between Ras/Rap and $\mathrm{PI}(4,5) \mathrm{P} 2 / \mathrm{PI}(3,4) \mathrm{P} 2$ can be assigned to $\mathrm{F}$ and $B$, respectively, whereas there is negative feedback through PKBA/PKBR1, which is assigned to R. Interestingly, PIP3 as an activator of PKBA, plays a negative role in STEN, while it is also an important positive regulator to actin polymerization (Figs. 1B and 4). The cytoskeletal network is also excitable and is referred to as the cytoskeletal excitable network (CEN) (Figs. 1B and 4A) (Li et al., 2018, Miao et al., 2019). The activities of CEN are more localized and rapid than those of STEN. Studies in Dictyostelium have shown that in the absence of signal transduction, these cytoskeletal events generate short, narrow protrusions, whereas coupling of STEN and CEN produces waves at the edge of cells followed by forward expansion of the membrane in the form of pseudopodia or broad lamellipodia-like protrusions (Huang et al., 2013, Miao et al., 2019, Shi et al., 2013, Tang et al., 2014, Vicker, 2002). Such correlations between signal transduction and actin waves, and leading edge protrusions are also found in mammalian cells such as neutrophils (Weiner et al., 2007), fibroblasts (Jalal et al., 2019, Zhang et al., 2018), keratocytes (Barnhart et al., 2011) and cancer cells (Yang et al., 2018).

The non-linear feedback models suggest that alteration in individual components can have a significant impact on the overall excitability of the networks (Iglesias and Devreotes, 2012). In recent studies, the threshold for STEN activation was synthetically reduced, by either decreasing PIP2 level or increasing Ras/Rap activities at the cell cortex, which resulted in significantly increased speed and range of F-actin waves in Dictyostelium cells (Miao et al., 2017). Such a change in wave propagation resulted in expansion of small, cup-like protrusions to very wide, lamellipodia-like protrusions, and ultimately, caused changes in cellular migratory modes from amoeboid to keratocyte-like and oscillatory (Fig. 5) (Miao et al., 2019, Miao et al., 2017). This work further supports the idea that STEN-CEN coupling generates sustained protrusions of migrating cells. Moreover, such abrupt and reversible changes in migratory modes between amoeboid and gliding indicate that migratory behaviors demonstrated by various eukaryotic cells could arise from a basic mechanism of STEN-CEN coupling.

\section{Dictyostelium makes predictions about eukaryotic migration}

We propose that, as in Dictyostelium, wave patterns of signal transduction components control protrusive activities in mammalian 
cells. It has been previously reported that local production of PIP3 or Rac1 activation, by optogenetics, is sufficient to initiate actin growth cone-like "waves" in developing neurons or reorient polarity and guide migration in neutrophils (Graziano etal., 2017, Kakumoto and Nakata, 2013). Moreover, the ability of manipulations of key signaling molecules or enzymes to create migratory and hyperactive phenotypes in mammalian cells, can be interpreted as changes of wave propagation. Examples include SHIP1 or PTEN deletions in neutrophils show increased motility and recruitment to inflamed sites (Sarraj et al., 2009), overexpression of cancer-associated, membrane translocation-incompetent PTEN mutations showed increased cell proliferation and migration in breast epithelial cells (Nguyen et al., 2015), and mutations of K-Ras promote migration and invasion in various cancers (Chu etal., 2018, Kang etal., 2018, Mann et al., 2016, Millien et al., 2018, Stuelten et al., 2018). These studies point towards the possibility that STEN is the integration site of extrinsic cues which control migration. There is an increasing appreciation of the ability of cells to integrate environmental signals, such as chemoattractant stimuli, electric fields and mechanical forces, and to move accordingly. Integration of these environmental signals with STEN and CEN, and the various regulatory feedback loops involved between them may be sufficient to explain the vast array of protrusions and migratory modes observed in diverse eukaryotic cells under physiological and pathological conditions.

\section{Acknowledgements}

We thank all members of the P.N.D. laboratory for helpful suggestions for this work. We thank the Johns Hopkins University (JHU) Microscope Facility for confocal microscopy. This work was supported by NIH grant R35 GM118177 (to P.N.D.), AFOSR MURI FA95501610052, DARPA HR0011-16-C-0139, as well as NIH Grant S10 OD016374 (to S. Kuo of the JHU Microscope Facility).

\section{Author contributions}

D.S.P., T.B. and Y.M. contributed experimental data; D.S.P., X.L. and P.N.D. wrote the manuscript; T.B. conceptualized figure 2, X.L. prepared figures 1, 2, 4 and 5, and D.S.P. made figure 3; D.S.P., X.L., T.B., Y.M. and P.N.D. contributed to manuscript revision and approved the submitted version of the manuscript.

Competing financial interests

The authors declare no competing financial interests.

\section{References}

ALLEN, G.M., MOGILNER, A. and THERIOT, J.A. (2013). Electrophoresis of cellular membrane components creates the directional cue guiding keratocyte galvanotaxis. Curr Biol 23: 560-568.

ALVAREZ-GONZALEZ, B., MEILI, R., FIRTEL, R., BASTOUNIS, E., DEL ALAMO, J.C. and LASHERAS, J.C. (2014). Cytoskeletal Mechanics Regulating Amoeboid Cell Locomotion. Appl Mech Rev 66.

ANDERSON, K.I. and CROSS, R. (2000). Contact dynamics during keratocyte motility. Curr Biol 10: 253-260.

ANDRE, E., BRINK, M., GERISCH, G., ISENBERG, G., NOEGEL, A., SCHLEICHER, M., SEGALL, J.E. and WALLRAFF, E. (1989). A Dictyostelium mutant deficient in severin, an F-actin fragmenting protein, shows normal motility and chemotaxis. J. Cell Biol. 108: 985-995.

ARAI, Y., SHIBATA, T., MATSUOKA, S., SATO, M.J., YANAGIDA, T. and UEDA, M. (2010). Self-organization of the phosphatidylinositol lipids signaling system for random cell migration. Proc Natl Acad Sci USA 107: 12399-12404.

ARMITAGE, J.P. and HELLINGWERF, K.J. (2003). Light-induced behavioral responses (;phototaxis') in prokaryotes. Photosynth Res 76: 145-155.
ARTEMENKO, Y., LAMPERT, T.J. and DEVREOTES, P.N. (2014). Moving towards a paradigm: common mechanisms of chemotactic signaling in Dictyostelium and mammalian leukocytes. Cell Mol Life Sci 71: 3711-3747.

BAGGIOLINI, M. (2001). Chemokines in pathology and medicine. J Intern Med 250 91-104.

BAGORDA, A., MIHAYLOV, V.A. and PARENT, C.A. (2006). Chemotaxis: moving forward and holding on to the past. Thromb Haemost 95: 12-21.

BAGORDA, A. and PARENT, C.A. (2008). Eukaryotic chemotaxis at a glance. $J$. Cell. Sci. 121: 2621-2624.

BARNHART, E.L., ALLEN, G.M., JULICHER, F. and THERIOT, J.A. (2010). Bipedal locomotion in crawling cells. Biophys J 98: 933-942.

BARNHART, E.L., LEE, K.C., KEREN, K., MOGILNER, A. and THERIOT, J.A. (2011). An adhesion-dependent switch between mechanisms that determine motile cell shape. PLOS Biol 9: e1001059.

BEMENT, W.M., LEDA, M., MOE, A.M., KITA, A.M., LARSON, M.E., GOLDING A.E., PFEUTI, C., SU, K.C., MILLER, A.L., GORYACHEV, A.B. et al., (2015). Activator-inhibitor coupling between Rho signalling and actin assembly makes the cell cortex an excitable medium. Nat. Cell Biol. 17: 1471-1483.

BLASER, H., REICHMAN-FRIED, M., CASTANON, I., DUMSTREI, K., MARLOW, F.L., KAWAKAMI, K., SOLNICA-KREZEL, L., HEISENBERG, C.P. and RAZ, E. (2006). Migration of zebrafish primordial germ cells: a role for myosin contraction and cytoplasmic flow. Dev Cell 11: 613-627.

BOSGRAAF, L. and VAN HAASTERT, P.J. (2009). The ordered extension of pseudopodia by amoeboid cells in the absence of external cues. PLoS One 4: e5253.

BRETSCHNEIDER, T., DIEZ, S., ANDERSON, K., HEUSER, J., CLARKE, M., MULLER-TAUBENBERGER, A., KOHLER, J. and GERISCH, G. (2004). Dynamic actin patterns and Arp2/3 assembly at the substrate-attached surface of motile cells. Curr Biol 14: 1-10.

CAI, H., DAS, S., KAMIMURA, Y., LONG, Y., PARENT, C.A. and DEVREOTES, P.N. (2010). Ras-mediated activation of the TORC2-PKB pathway is critical for chemotaxis. J. Cell Biol. 190: 233-245.

CASE, L.B. and WATERMAN, C.M. (2011). Adhesive F-actin waves: a novel integrinmediated adhesion complex coupled to ventral actin polymerization. PLoS One 6: e26631.

CHAREST, P.G., SHEN, Z., LAKODUK, A., SASAKI, A.T., BRIGGS, S.P. and FIRTEL, R.A. (2010). A Ras signaling complex controls the RasC-TORC2 pathway and directed cell migration. Dev Cell 18: 737-749.

CHEN, L., JANETOPOULOS, C., HUANG, Y.E., IIJIMA, M., BORLEIS, J. and DEVREOTES, P.N. (2003). Two phases of actin polymerization display different dependencies on $\mathrm{PI}(3,4,5) \mathrm{P} 3$ accumulation and have unique roles during chemotaxis. Mol Biol Cell 14: 5028-5037.

CHISHOLM, R.L. and FIRTEL, R.A. (2004). Insights into morphogenesis from a simple developmental system. Nat Rev Mol Cell Biol 5: 531-541.

CHU, P.C., LIN, P.C., WU, H.Y., LIN, K.T., WU, C., BEKAII-SAAB, T., LIN, Y.J., LEE, C.T., LEE, J.C. and CHEN, C.S. (2018). Mutant KRAS promotes liver metastasis of colorectal cancer, in part, by upregulating the MEK-Sp1-DNMT1-miR-137-YB1-IGF-IR signaling pathway. Oncogene 37: 3440-3455.

COLIN-YORK, H., LI, D., KOROBCHEVSKAYA, K., CHANG, V.T., BETZIG, E., EGGELING, C. and FRITZSCHE, M. (2019). Cytoskeletal actin patterns shape mast cell activation. Commun Biol 2: 93.

CORTESE, B., PALAMA, I.E., D'AMONE, S. and GIGLI, G. (2014). Influence of electrotaxis on cell behaviour. Integr Biol (Camb) 6: 817-830.

DE HOSTOS, E.L., BRADTKE, B., LOTTSPEICH, F., GUGGENHEIM, R. and GERISCH, G. (1991). Coronin, an actin binding protein of Dictyostelium discoideum localized to cell surface projections, has sequence similarities to $G$ protein beta subunits. EMBO J 10: 4097-4104.

DE LOZANNE, A. and SPUDICH, J.A. (1987). Disruption of the Dictyostelium myosin heavy chain gene by homologous recombination. Science 236: 1086-1091.

DEVREOTES, P. and HORWITZ, A.R. (2015). Signaling networks that regulate cell migration. Cold Spring Harb Perspect Biol 7: a005959.

DEVREOTES, P.N., BHATTACHARYA, S., EDWARDS, M., IGLESIAS, P.A., LAMPERT, T. and MIAO, Y. (2017). Excitable Signal Transduction Networks in Directed Cell Migration. Annu Rev Cell Dev Biol 33: 103-125.

DUMSTREI, K., MENNECKE, R. and RAZ, E. (2004). Signaling pathways controlling primordial germ cell migration in zebrafish. J. Cell. Sci. 117: 4787-4795. 
FACKLER, O.T. and GROSSE, R. (2008). Cell motility through plasma membrane blebbing. J. Cell Biol. 181: 879-884.

FERGUSON, G.J., MILNE, L., KULKARNI, S., SASAKI, T., WALKER, S., ANDREWS, S., CRABBE, T., FINAN, P., JONES, G., JACKSON, S. et al., (2007). PI(3) Kgamma has an important context-dependent role in neutrophil chemokinesis. Nat. Cell Biol. 9: 86-91.

FILIC, V., MARINOVIC, M., FAIX, J. and WEBER, I. (2012). A dual role for Rac1 GTPases in the regulation of cell motility. J. Cell. Sci. 125: 387-98.

FUKUSHIMA, S., MATSUOKA, S. and UEDA, M. (2019). Excitable dynamics of Ras triggers spontaneous symmetry breaking of PIP3 signaling in motile cells. J. Cell. Sci. 132.

FUNAMOTO, S., MEILI, R., LEE, S., PARRY, L. and FIRTEL, R.A. (2002). Spatial and temporal regulation of 3-phosphoinositides by PI 3-kinase and PTEN mediates chemotaxis. Cell 109: 611-23.

GAO, R.C., ZHANG, X.D., SUN, Y.H., KAMIMURA, Y., MOGILNER, A., DEVREOTES, P.N. and ZHAO, M. (2011). Different roles of membrane potentials in electrotaxis and chemotaxis of dictyostelium cells. Eukaryot Cell 10: 1251-6.

GERHARDT, M., ECKE, M., WALZ, M., STENGL, A., BETA, C. and GERISCH, G. (2014). Actin and PIP3 waves in giant cells reveal the inherent length scale of an excited state. J. Cell. Sci. 127: 4507-17.

GERISCH, G. (2010). Self-organizing actin waves that simulate phagocytic cup structures. PMC Biophys 3: 7 .

GERISCH, G., ECKE, M., NEUJAHR, R., PRASSLER, J., STENGL, A., HOFFMANN, M., SCHWARZ, U.S. and NEUMANN, E. (2013). Membrane and actin reorganization in electropulse-induced cell fusion. J. Cell. Sci. 126: 2069-2078.

GERISCH, G., ECKE, M., WISCHNEWSKI, D. and SCHROTH-DIEZ, B. (2011). Different modes of state transitions determine pattern in the Phosphatidylinositide-Actin system. BMC Cell Biol 12: 42.

GERISCH, G., SCHROTH-DIEZ, B., MULLER-TAUBENBERGER, A. and ECKE, M. (2012). PIP3 waves and PTEN dynamics in the emergence of cell polarity. Biophys J 103: 1170-8.

GRAZIANO, B.R., GONG, D., ANDERSON, K.E., PIPATHSOUK, A., GOLDBERG, A.R. and WEINER, O.D. (2017). A module for Rac temporal signal integration revealed with optogenetics. J. Cell Biol. 216: 2515-2531.

HARLAND, B., WALCOTT, S. and SUN, S.X. (2011). Adhesion dynamics and durotaxis in migrating cells. Phys Biol 8: 015011.

HECHT, I., KESSLER, D.A. and LEVINE, H. (2010). Transient localized patterns in noise-driven reaction-diffusion systems. Phys Rev Lett 104: 158301

HEPPER, I., SCHYMEINSKY, J., WECKBACH, L.T., JAKOB, S.M., FROMMHOLD, D., SIXT, M., LASCHINGER, M., SPERANDIO, M. and WALZOG, B. (2012). The mammalian actin-binding protein 1 is critical for spreading and intraluminal crawling of neutrophils under flow conditions. J Immunol 188: 4590-601.

HOELLER, O. and KAY, R.R. (2007). Chemotaxis in the absence of PIP3 gradients. Curr Biol 17: 813-817.

HOU, Y., HEDBERG, S. and SCHNEIDER, I.C. (2012). Differences in adhesion and protrusion properties correlate with differences in migration speed under EGF stimulation. BMC Biophys 5: 8.

HUANG, C.H., TANG, M., SHI, C., IGLESIAS, P.A. and DEVREOTES, P.N. (2013). An excitable signal integrator couples to an idling cytoskeletal oscillator to drive cell migration. Nat. Cell Biol. 15: 1307-16.

IGLESIAS, P.A. and DEVREOTES, P.N. (2012). Biased excitable networks: how cells direct motion in response to gradients. Curr. Opin. Cell Biol. 24: 245-253.

IIJIMA, M. and DEVREOTES, P. (2002). Tumor suppressor PTEN mediates sensing of chemoattractant gradients. Cell 109: 599-610.

IIJIMA, M., HUANG, Y.E., LUO, H.R., VAZQUEZ, F. and DEVREOTES, P.N. (2004). Novel mechanism of PTEN regulation by its phosphatidylinositol 4,5-bisphosphate binding motif is critical for chemotaxis. J Biol Chem 279: 16606-13.

INOUE, T. and MEYER, T. (2008). Synthetic activation of endogenous PI3K and Rac identifies an AND-gate switch for cell polarization and migration. PLoSOne3: e3068.

INSALL, R.H., BORLEIS, J. and DEVREOTES, P.N. (1996). The aimless RasGEF is required for processing of chemotactic signals through G-protein-coupled receptors in Dictyostelium. Curr Biol 6: 719-29.

JALAL, S., SHI, S., ACHARYA, V., HUANG, R.Y., VIASNOFF, V., BERSHADSKY, A.D. and TEE, Y.H. (2019). Actin cytoskeleton self-organization in single epithelial cells and fibroblasts under isotropic confinement. J. Cell. Sci. 132
JANETOPOULOS, C., BORLEIS, J., VAZQUEZ, F., IIJIMA, M. and DEVREOTES, P. (2005). Temporal and spatial regulation of phosphoinositide signaling mediates cytokinesis. Dev Cell 8: 467-77.

JANETOPOULOS, C., MA, L., DEVREOTES, P.N. and IGLESIAS, P.A. (2004) Chemoattractant-induced phosphatidylinositol 3,4,5-trisphosphate accumulation is spatially amplified and adapts, independent of the actin cytoskeleton. Proc Natl Acad Sci USA 101: 8951-6.

JIN, T., XU, X. and HERELD, D. (2008). Chemotaxis, chemokine receptors and human disease. Cytokine 44: 1-8

JUNG, G., WU, X. and HAMMER, J.A., 3RD. (1996). Dictyostelium mutants lacking multiple classic myosin I isoforms reveal combinations of shared and distinct functions. J. Cell Biol. 133: 305-23.

KAE, H., LIM, C.J., SPIEGELMAN, G.B. and WEEKS, G. (2004). Chemoattractantinduced Ras activation during Dictyostelium aggregation. EMBO Rep 5: 602-6.

KAKUMOTO, T. and NAKATA, T. (2013). Optogenetic control of PIP3: PIP3 is sufficient to induce the actin-based active part of growth cones and is regulated via endocytosis. PLoS One 8: e70861.

KANG, K., ZHANG, J., ZHANG, X. and CHEN, Z. (2018). MicroRNA-326 inhibits melanoma progression by targeting KRAS and suppressing the AKT and ERK signalling pathways. Oncol Rep 39: 401-410.

KEDRIN, D., VAN RHEENEN, J., HERNANDEZ, L., CONDEELIS, J. and SEGALL, J.E. (2007). Cell motility and cytoskeletal regulation in invasion and metastasis. J Mammary Gland Biol Neoplasia 12: 143-52.

KELLER, R. (2005). Cell migration during gastrulation. Curr Opin Cell Biol 17: 533-41.

KHANNA, A., LOTFI, P., CHAVAN, A.J., MONTANO, N.M., BOLOURANI, P., WEEKS G., SHEN, Z., BRIGGS, S.P., POTS, H., VAN HAASTERT, P.J. et al., (2016). The small GTPases Ras and Rap1 bind to and control TORC2 activity. Sci Rep 6:25823.

KIMMEL, A.R. and PARENT, C.A. (2003). The signal to move: D. discoideum go orienteering. Science 300: 1525-1527.

KLAMBT, C. (2009). Modes and regulation of glial migration in vertebrates and invertebrates. Nat Rev Neurosci 10: 769-779.

KLEIN, P.S., SUN, T.J., SAXE, C.L., 3RD, KIMMEL, A.R., JOHNSON, R.L. and DEVREOTES, P.N. (1988). A chemoattractant receptor controls development in Dictyostelium discoideum. Science 241: 1467-1472.

KRIEBEL, P.W., BARR, V.A., RERICHA, E.C., ZHANG, G. and PARENT, C.A. (2008) Collective cell migration requires vesicular trafficking for chemoattractant delivery at the trailing edge. J. Cell Biol. 183: 949-961.

LAKSHMAN, R. and FINN, A. (2001). Neutrophil disorders and their management $J$ Clin Pathol 54: 7-19.

LAM, P.Y., YOO, S.K., GREEN, J.M. and HUTTENLOCHER, A. (2012). The SH2domain-containing inositol 5-phosphatase (SHIP) limits the motility of neutrophils and their recruitment to wounds in zebrafish. J. Cell. Sci. 125: 4973-4978.

LAWSON, C.D. and RIDLEY, A.J. (2018). Rho GTPase signaling complexes in cell migration and invasion. J. Cell Biol. 217: 447-457.

LEPTIN, M. (2005). Gastrulation movements: the logic and the nuts and bolts. Dev Cell 8: 305-320.

LI, X., EDWARDS, M., SWANEY, K.F., SINGH, N., BHATTACHARYA, S., BORLEIS, J., LONG, Y., IGLESIAS, P.A., CHEN, J. and DEVREOTES, P.N. (2018). Mutually inhibitory Ras-PI(3,4)P2 feedback loops mediate cell migration. Proc Natl Acad Sci USA 115: E9125-E9134.

LIM, C.J., SPIEGELMAN, G.B. and WEEKS, G. (2002). Cytoskeletal regulation by Dictyostelium Ras subfamily proteins. J Muscle Res Cell Motil 23: 729-736.

LO, C.M., WANG, H.B., DEMBO, M. and WANG, Y.L. (2000). Cell movement is guided by the rigidity of the substrate. Biophys J 79: 144-152.

MAHADEO, D.C. and PARENT, C.A. (2006). Signal relay during the life cycle of Dictyostelium. Curr Top Dev Biol 73: 115-140.

MANES, S., GOMEZ-MOUTON, C., LACALLE, R.A., JIMENEZ-BARANDA, S. MIRA, E. and MARTINEZ, A.C. (2005). Mastering time and space: immune cell polarization and chemotaxis. Semin Immunol 17: 77-86.

MANN, K.M., YING, H., JUAN, J., JENKINS, N.A. and COPELAND, N.G. (2016). KRAS-related proteins in pancreatic cancer. Pharmacol Ther 168: 29-42.

MARCHESIN, V., MONTAGNAC, G. and CHAVRIER, P. (2015). ARF6 promotes the formation of Rac1 and WAVE-dependent ventral F-actin rosettes in breas cancer cells in response to epidermal growth factor. PLoS One 10: e0121747. 
MASTERS, T.A., SHEETZ, M.P. and GAUTHIER, N.C. (2016). F-actin waves, actin cortex disassembly and focal exocytosis driven by actin-phosphoinositide positive feedback. Cytoskeleton (Hoboken) 73: 180-196.

MATSUOKA, S. and UEDA, M. (2018). Mutual inhibition between PTEN and PIP3 generates bistability for polarity in motile cells. Nat. Comm. 9.

MEINHARDT, H. and DE BOER, P.A. (2001). Pattern formation in Escherichia coli: a model for the pole-to-pole oscillations of Min proteins and the localization of the division site. Proc Natl Acad Sci USA 98: 14202-14207.

MENG, X., AROCENA, M., PENNINGER, J., GAGE, F.H., ZHAO, M. and SONG, B. (2011). PI3K mediated electrotaxis of embryonic and adult neural progenitor cells in the presence of growth factors. Exp Neurol 227: 210-217.

MIAO, Y., BHATTACHARYA, S., BANERJEE, T., ABUBAKER-SHARIF, B., LONG, Y., INOUE, T., IGLESIAS, P.A. and DEVREOTES, P.N. (2019). Wave patterns organize cellular protrusions and control cortical dynamics. Mol Syst Biol 15: e8585.

MIAO, Y., BHATTACHARYA, S., EDWARDS, M., CAI, H., INOUE, T., IGLESIAS, P.A. and DEVREOTES, P.N. (2017). Altering the threshold of an excitable signal transduction network changes cell migratory modes. Nat. Cell Biol. 19: 329-340.

MILLIEN, G., CAO, Y., O'HARA, C.J., TAGNE, J.B., HINDS, A., WILLIAMS, M.C., RAMIREZ, M.I. and KATHURIA, H. (2018). ETS1 regulates Twist1 transcription in a $\operatorname{Kras}(\mathrm{G12D}) / \mathrm{Lkb1}(-/-)$ metastatic lung tumor model of non-small cell lung cancer. Clin Exp Metastasis 35: 149-165.

MOGILNER, A. and KEREN, K. (2009). The shape of motile cells. Curr Biol 19: R762-R771.

MONTELL, D.J. (2008). Morphogenetic cell movements: diversity from modular mechanical properties. Science 322: 1502-1505.

MOULDING, D.A., RECORD, J., MALINOVA, D. and THRASHER, A.J. (2013). Actin cytoskeletal defects in immunodeficiency. Immunol Rev 256: 282-299.

MULLER-TAUBENBERGER, A., KORTHOLT, A. and EICHINGER, L. (2013). Simple system--substantial share: the use of Dictyostelium in cell biology and molecular medicine. Eur J Cell Biol 92: 45-53.

NGUYEN, H.N., YANG, J.M., JR., RAHDAR, M., KENIRY, M., SWANEY, K.F., PARSONS, R., PARK, B.H., SESAKI, H., DEVREOTES, P.N. and IIJIMA, M. (2015). A new class of cancer-associated PTEN mutations defined by membrane translocation defects. Oncogene 34: 3737-3743.

NISHIO, M., WATANABE, K., SASAKI, J., TAYA, C., TAKASUGA, S., IIZUKA, R., BALLA, T., YAMAZAKI, M., WATANABE, H., ITOH, R. et al., (2007). Control of cell polarity and motility by the Ptdlns $(3,4,5) \mathrm{P} 3$ phosphatase SHIP1. Nat. Cell Biol. 9: 36-44.

NOURSHARGH, S. and ALON, R. (2014). Leukocyte migration into inflamed tissues Immunity 41: 694-707.

PAN, M., XU, X., CHEN, Y. and JIN, T. (2016). Identification of a Chemoattractant G-Protein-Coupled Receptor for Folic Acid that Controls Both Chemotaxis and Phagocytosis. Dev Cell 36: 428-439.

PARENT, C.A. (2004). Making all the right moves: chemotaxis in neutrophils and Dictyostelium. Curr Opin Cell Biol 16: 4-13.

PARENT, C.A., BLACKLOCK, B.J., FROEHLICH, W.M., MURPHY, D.B. and DEVREOTES, P.N. (1998). G protein signaling events are activated at the leading edge of chemotactic cells. Cell 95: 81-91.

PARENT, C.A. and DEVREOTES, P.N. (1996). Molecular genetics of signal transduction in Dictyostelium. Annu Rev Biochem 65: 411-440.

PARSONS, J.T., HORWITZ, A.R. and SCHWARTZ, M.A. (2010). Cell adhesion: integrating cytoskeletal dynamics and cellular tension. Nat Rev Mol Cell Biol 11: 633-643.

RAMOT, D., MACINNIS, B.L., LEE, H.C. and GOODMAN, M.B. (2008). Thermotaxis is a robust mechanism for thermoregulation in Caenorhabditis elegans nematodes. J Neurosci 28: 12546-12557.

RICHARDSON, B.E. and LEHMANN, R. (2010). Mechanisms guiding primordial germ cell migration: strategies from different organisms. Nat Rev Mol Cell Biol 11:37-49.

RIDLEY, A.J. (2015). Rho GTPase signalling in cell migration. Curr. Opin. Cell Biol. 36: $103-112$.

SARRAJ, B., MASSBERG, S., LI, Y., KASORN, A., SUBRAMANIAN, K., LOISON, F., SILBERSTEIN, L.E., VON ANDRIAN, U. and LUO, H.R. (2009). Myeloid-specific deletion of tumor suppressor PTEN augments neutrophil transendothelial migration during inflammation. J Immunol 182: 7190-7200.

SASAKI, A.T., CHUN, C., TAKEDA, K. and FIRTEL, R.A. (2004). Localized Ras signaling at the leading edge regulates $\mathrm{PI} 3 \mathrm{~K}$, cell polarity, and directional cell movement. J. Cell Biol. 167: 505-518.

SASAKI, A.T., JANETOPOULOS, C., LEE, S., CHAREST, P.G., TAKEDA, K. SUNDHEIMER, L.W., MEILI, R., DEVREOTES, P.N. and FIRTEL, R.A. (2007). G protein-independent Ras/PI3K/F-actin circuit regulates basic cell motility. $J$. Cell Biol. 178: 185-191.

SENOO, H., KAMIMURA, Y., KIMURA, R., NAKAJIMA, A., SAWAI, S., SESAKI, H. and IIJIMA, M. (2019). Phosphorylated Rho-GDP directly activates mTORC2 kinase towards AKT through dimerization with Ras-GTP to regulate cell migration. Nat. Cell Biol. 21: 867-+.

SENOO, H., SESAKI, H. and IIJIMA, M. (2016). A GPCR Handles Bacterial Sensing in Chemotaxis and Phagocytosis. Dev Cell 36: 354-356.

SHAW, T.J. and MARTIN, P. (2009). Wound repair at a glance. J. Cell. Sci. 122: 3209-3213.

SHI, C., HUANG, C.H., DEVREOTES, P.N. and IGLESIAS, P.A. (2013). Interaction of motility, directional sensing, and polarity modules recreates the behaviors of chemotaxing cells. PLoS Comput Biol 9: e1003122.

SIMANSHU, D.K., NISSLEY, D.V. and MCCORMICK, F. (2017). RAS Proteins and Their Regulators in Human Disease. Cell 170: 17-33.

STEPHENS, L., MILNE, L. and HAWKINS, P. (2008). Moving towards a better understanding of chemotaxis. Curr Biol 18: R485-R494.

STUELTEN, C.H., PARENT, C.A. and MONTELL, D.J. (2018). Cell motility in cancer invasion and metastasis: insights from simple model organisms. Nat Rev Cancer 18: 296-312.

SWANEY, K.F., HUANG, C.H. and DEVREOTES, P.N. (2010). Eukaryotic chemotaxis: a network of signaling pathways controls motility, directional sensing, and polarity Annu Rev Biophys 39: 265-89.

TANG, M., IIJIMA, M., KAMIMURA, Y., CHEN, L., LONG, Y. and DEVREOTES, P. (2011). Disruption of PKB signaling restores polarity to cells lacking tumor suppressor PTEN. Mol Biol Cell 22: 437-47.

TANG, M., WANG, M., SHI, C., IGLESIAS, P.A., DEVREOTES, P.N. and HUANG C.H. (2014). Evolutionarily conserved coupling of adaptive and excitable networks mediates eukaryotic chemotaxis. Nat. Comm. 5: 5175

TESSIER-LAVIGNE, M. (1994). Axon guidance by diffusible repellants and attractants Curr Opin Genet Dev 4: 596-601.

THEVENEAU, E. and MAYOR, R. (2012). Neural crest delamination and migration: from epithelium-to-mesenchyme transition to collective cell migration. Dev Biol 366: 34-54.

TSAI, T.Y.C., COLLINS, S.R., CHAN, C.K., HADJITHEODOROU, A., LAM, P.Y., LOU, S.S., YANG, H.W., JORGENSEN, J., ELLETT, F., IRIMIA, D. et al., (2019). Efficient Front-Rear Coupling in Neutrophil Chemotaxis by Dynamic Myosin II Localization. Dev. Cell 49: 189-205.

VICKER, M.G. (2002). F-actin assembly in Dictyostelium cell locomotion and shape oscillations propagates as a self-organized reaction-diffusion wave. FEBS Lett 510: 5-9

WANG, Y., KU, C.J., ZHANG, E.R., ARTYUKHIN, A.B., WEINER, O.D., WU, L.F. and ALTSCHULER, S.J. (2013a). Identifying network motifs that buffer front-to-back signaling in polarized neutrophils. Cell Rep 3: 1607-1616.

WANG, Y., SENOO, H., SESAKI, H. and IIJIMA, M. (2013b). Rho GTPases orient directional sensing in chemotaxis. Proc Natl Acad Sci USA 110: E4723-E4732.

WEINER, O.D., MARGANSKI, W.A., WU, L.F., ALTSCHULER, S.J. and KIRSCHNER M.W. (2007). An actin-based wave generator organizes cell motility. PLoS Biol 5: e221

WENINGER, W., BIRO, M. and JAIN, R. (2014). Leukocyte migration in the interstitia space of non-lymphoid organs. Nat Rev Immunol 14: 232-246.

WESSELS, D., SOLL, D.R., KNECHT, D., LOOMIS, W.F., DE LOZANNE, A. and SPUDICH, J. (1988). Cell motility and chemotaxis in Dictyostelium amebae lacking myosin heavy chain. Dev Biol 128: 164-177.

WHITAKER, B.D. and POFF, K.L. (1980). Thermal adaptation of thermosensing and negative thermotaxis in Dictyostelium. Exp Cell Res 128: 87-93.

WILKINS, A. and INSALL, R.H. (2001). Small GTPases in Dictyostelium: lessons from a social amoeba. Trends Genet 17: 41-48.

WINANS, A.M., COLLINS, S.R. and MEYER, T. (2016). Waves of actin and microtubule polymerization drive microtubule-based transport and neurite growth before single axon formation. Elife 5: e12387.

WITKE, W., SCHLEICHER, M. and NOEGEL, A.A. (1992). Redundancy in the 


\section{D.S. Pal et al.}

microfilament system: abnormal development of Dictyostelium cells lacking two F-actin cross-linking proteins. Cell 68: 53-62.

WU, L.J. and DEVREOTES, P.N. (1991). Dictyostelium transiently expresses eight distinct G-protein alpha-subunits during its developmental program. Biochem Biophys Res Commun 179: 1141-1147.

WU, M., WU, X. and DE CAMILLI, P. (2013). Calcium oscillations-coupled conversion of actin travelling waves to standing oscillations. Proc Natl Acad Sci USA 110: 1339-1344.

XIONG, D., XIAO, S., GUO, S., LIN, Q., NAKATSU, F. and WU, M. (2016). Frequency and amplitude control of cortical oscillations by phosphoinositide waves. Nat Chem Biol 12: 159-166.

XIONG, Y., HUANG, C.H., IGLESIAS, P.A. and DEVREOTES, P.N. (2010). Cells navigate with a local-excitation, global-inhibition-biased excitable network. Proc Natl Acad Sci USA 107: 17079-17086.

XU, X.H., WEN, X., VELTMAN, D.M., KEIZER-GUNNINK, I., POTS, H., KORTHOLT, A. and JIN, T. (2017). GPCR-controlled membrane recruitment of negative regulator C2GAP1 locally inhibits Ras signaling for adaptation and long-range chemotaxis. Proc. Natl. Acad. Sci. USA 114: E10092-E10101.
YANG, J.M., BHATTACHARYA, S., WEST-FOYLE, H., HUNG, C.F., WU, T.C., IGLESIAS, P.A. and HUANG, C.H. (2018). Integrating chemical and mechanical signals through dynamic coupling between cellular protrusions and pulsed ERK activation. Nat. Comm. 9: 4673.

YANG, X., DORMANN, D., MUNSTERBERG, A.E. and WEIJER, C.J. (2002). Cell movement patterns during gastrulation in the chick are controlled by positive and negative chemotaxis mediated by FGF4 and FGF8. Dev Cell 3: 425-437.

YOSHIDA, K. and SOLDATI, T. (2006). Dissection of amoeboid movement into two mechanically distinct modes. J. Cell. Sci. 119: 3833-3844.

ZHANG, K., LYU, W., YU, J. and KOLESKE, A.J. (2018). Abl2 is recruited to ventral actin waves through cytoskeletal interactions to promote lamellipodium extension. Mol Biol Cell 29: 2863-2873.

ZHAO, M., JIN, T., MCCAIG, C.D., FORRESTER, J.V. and DEVREOTES, P.N. (2002) Genetic analysis of the role of $\mathrm{G}$ protein-coupled receptor signaling in electrotaxis. J. Cell Biol. 157: 921-927.

ZHAO, M., SONG, B., PU, J., WADA, T., REID, B., TAI, G., WANG, F., GUO, A., WALCZYSKO, P., GU, Y. et al., (2006). Electrical signals control wound healing through phosphatidylinositol-3-OH kinase-gamma and PTEN. Nature442: 457-460. 


\section{Further Related Reading, published previously in the Int. J. Dev. Biol.}

Deletion of etoposide-induced 2.4 kb transcript (ei24) reduced cell proliferation and aggregate-size in Dictyostelium discoideum Neha Gupta and Shweta Saran

Int. J. Dev. Biol. (2018) 62: 273-283

https://doi.org/10.1387/ijdb.170327ss

The Dictyostelium prestalk inducer DIF-1 directs phosphorylation of a bZIP transcription factor

Yoko Yamada, Yuzuru Kubohara, Haruhisa Kikuchi, Yoshiteru Oshima, Hong-Yu Wang, Susan Ross and Jeffrey G. Williams Int. J. Dev. Biol. (2013) 57: 375-381

https://doi.org/10.1387/ijdb.130046jw

An orthologue of the Myelin-gene Regulatory Transcription Factor regulates Dictyostelium prestalk differentiation Hiroshi Senoo, Hong-Yu Wang, Tsuyoshi Araki, Jeffrey G. Williams and Masashi Fukuzawa Int. J. Dev. Biol. (2012) 56: 325-334

https://doi.org/10.1387/ijdb.120030jw

Bimodal distribution of motility and cell fate in Dictyostelium discoideum Pavana Goury-Sistla, Vidyanand Nanjundiah and Gopal Pande Int. J. Dev. Biol. (2012) 56: 263-272

https://doi.org/10.1387/ijdb.113384ps

ASET/MYND chromatin re-modelling protein regulates Dictyostelium prespore patterning Beatriz Nuñez-Corcuera, Joanna Birch and Jeffrey G. Williams Int. J. Dev. Biol. (2011) 55: 205-208

https://doi.org/10.1387/ijdb.113309bn

Pattern formation mechanisms in reaction-diffusion systems

Vladimir K. Vanag and Irving R. Epstein

Int. J. Dev. Biol. (2009) 53: 673-681

https://doi.org/10.1387/ijdb.072484vv

Regulation of cell differentiation and pattern formation in Dictyostelium development I Takeuchi, M Tasaka, K Okamoto and Y Maeda Int. J. Dev. Biol. (1994) 38: 311-319

http://www.intjdevbiol.com/web/paper/7981039
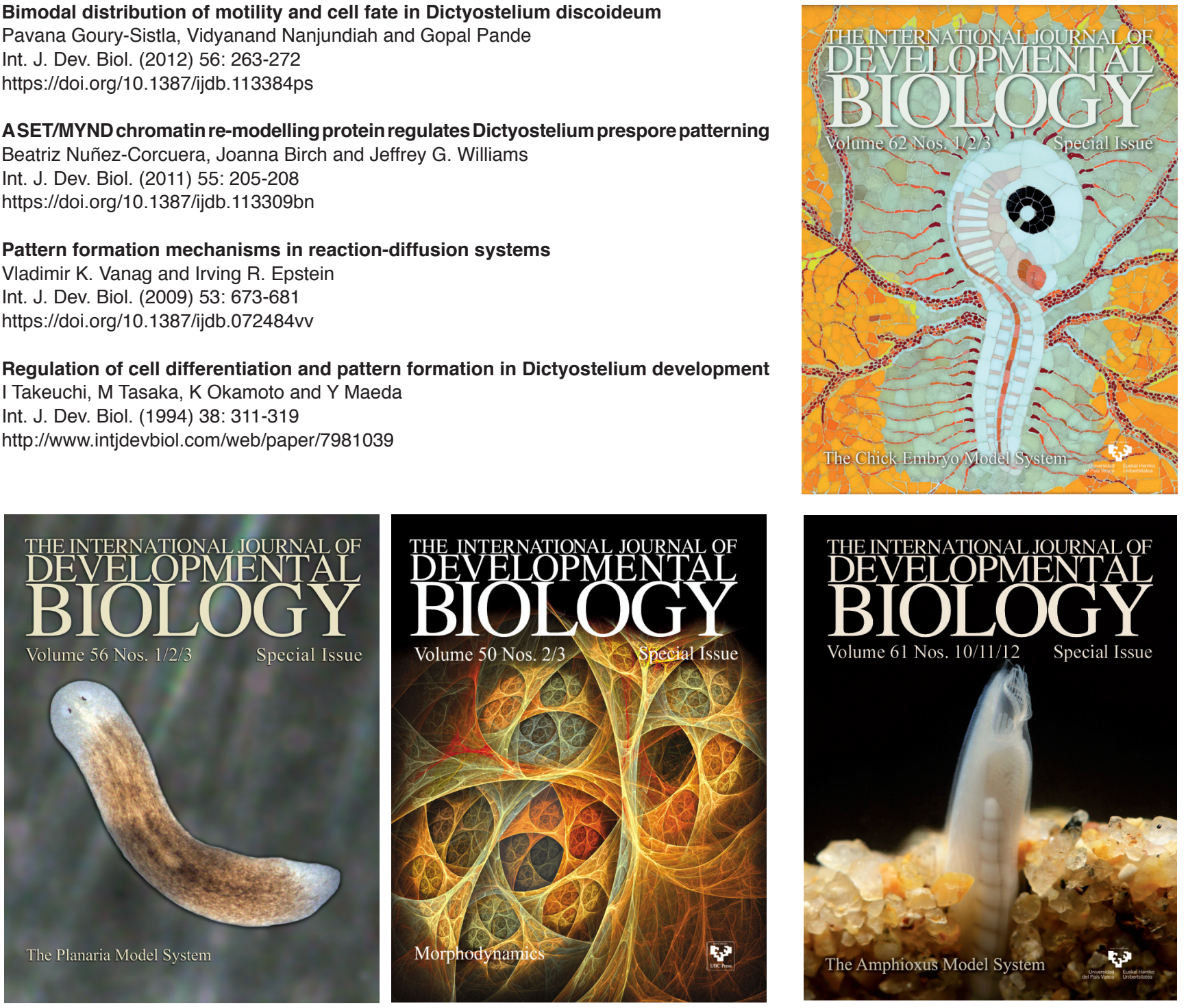